\title{
HUKUM PERBANKAN DALAM SISTEM OPERASIONAL BANK KONVENSIONAL DAN BANK SYARIAH
}

\author{
Moh. Ali Wafa \\ Fakultas Syariah dan Hukum UIN Syarif Hidayatullah Jakarta \\ J. Ir. H. Juanda. No 95 Ciputat Tanggerang Selatan \\ Email :m.aliwafa@yahoo.com
}

\begin{abstract}
Banking Law in the Operational System of Conventional and Sharia Banks. It is a big phenomenon in Indonesian banking with the establishment of Sharia Bank. As the result, people have an alternative to choose the services between Conventional Bank or Sharia Bank. With the consideration that Conventional Bank is using the operational system of foregone interest (effective interest) and Sharia Bank is using the profit-sharing operational system, which is based on Mutanaqisah principle (the combination of Musharakah and Ijarah) in Islamic law.
\end{abstract}

Keywords: system, interest, bank, mudharabah, Islam

\begin{abstract}
Abstrak: $\quad$ Hukum Perbankan dalam Sistem Operasional Bank Konvensional dan Bank Syariah. Dengan terbentuknya Bank Syariah, merupakan fenomena besar dalam dunia perbankan di Indonesia, sehingga masyarakat memiliki alternatif untuk memiliki jasa Bank Konvensional atau bank syariah. Dengan pertimbangan bahwa bank konvesional menggunakan sistem operasional interest foregone (bunga efektif) dan bank syariah menggunakan sistem operasional bagi hasil berdasarkan prinsip masyarakat al mutanaqisah (kombinasi musyarakah dan ijarah) dalam ketentuan syariat Islam.
\end{abstract}

Kata Kunci: sistem, bunga, bank, mudharabah, Islam 


\section{Pendahuluan}

Perbankan merupakan inti dari suatu keuangan setiap negara, bank merupakan lembaga keuangan yang menjadi tempat bagi perusahaan, badan-badan pemerintahan dan swasta maupun perorangan menyimpan dana-dananya baik melalui kegiatan perkreditan dan berbagai jasa yang dapat diberikan, baik melayani kebutuhan pembiayaan serta melancarkan mekanisme sistem pembangunan bagi semua sektor perekonomian.

Dengan memberikan kredit kepada beberapa sektor perekonomian, bank melancarkan arus barang-barang dan jasa dari produsen kepada konsumen. Bank merupakan supplier dari sebagian besar uang yang beredar dengan digunakan sebagai alat tukar, sehingga mekanisme kebijaksanaan moneter dapat berjalan. Dengan demikian bank merupakan suatu lembaga keuangan yang sangat penting dalam menjalankan kegiatan perekonomian dan perdagangan.

Di dalam Islam, masalah perbankan tidak diatur dalam nash secara tegas dan jelas, sehingga merupakan masalah ijtihadiyah dan terdapat kontroversial dalam kepastian hukumnya. Kontroversial ini terjadi karena sistem yang dianut perbankan konvensional menggunakan sistem bunga (interest foregone), sementara dalam agama Islam setiap investasi yang mengandung unsur riba adalah haram.

Terlepas dari hal tersebut, kebutuhan masyarakat terhadap jasa perbankan sangat besar karena bank sebagai penghimpun dan penyalur dana masyarakat. Demikian pula dalam perbankan terdapat pihak penerima jasa dan pemberi jasa. Oleh karena itu pemerintah merespon masalah tersebut berupa diterbitkannya peraturan Pemerintah RI No. 72 Tahun 1992. Tentang Pendirian Bank berdasarkan prinsip bagi hasil (Bank Syariah). Keadaan ini memberikan nuansa semakin bervariasinya landasan operasional bank di Indonesia dan memberikan pilihan kepada masyarakat muslim khususnya untuk menggunakan jasa perbankan syariah. Perbankan syariah merupakan lembaga keuangan sebagai penghimpun dana dan penyalur dan masyarakat khususnya masyarakat muslim menetapkan imbalan berdasarkan sistem bagi hasil tergolong masih baru berdiri di Indonesia dan masih terbatas di beberapa tempat tertentu saja di Indonesia, sehingga masyarakat belum begitu banyak tahu tentang mekanisme kerja dan 
sistem operasional bank syariah sehingga menimbulkan keuangan masyarakat untuk menggunakan jasa perbankan syariah.

Dengan demikian, artiel ini menyajikan pengertian bank konvensional dan bank syariah, awal mula terbentuknya bank konvensional dan bank syariah, sistem operasional bank konvensional dan bank syariah serta persamaan dan perbedaan kedua sistem tersebut. (sistem bunga dan sistem bagi hasil).

\section{Bank Konvensional Sebuah Kajian Teori Antara Sistem dan Operasional}

Bank berasal dari bahasa italia yakni "Banco" yang berarti kepingan papan untuk buku sejenis meja. ${ }^{1}$ Dan diperluas lagi untuk menunjukkan tempat penukaran uang, untuk memamerkan uang dan difungsikan oleh para pemberi pinjaman dan para pedagang valuta eropa pada abad pertengahan. ${ }^{2}$ Menurut G.M. Verryn Struart, bank adalah suatu badan yang bertujuan untuk memuaskan kebutuhan kredit baik dengan alat-alat pembayarannya sendiri atau dengan uang yang diperoleh dari orang lain maupun dengan jalan memperedarkan alat-alat penukaran baru dengan giral. ${ }^{3}$ Dalam Undang-undang No. 14 Tahun 19667 pasal 1 Bank dapat diartikan suatu lembaga keuangan yang usaha pokoknya memberikan kredit dan jasa-jasa dalam lalu lintas pembayaran dan peredaran uang. ${ }^{4}$ Demikian pula dalam Undang-undang No.7 Tahun 1992 Bab 1 Pasa 1.1. Bahwa bank itu adalah badan usaha yang menghimpun dana dari masyarakat dalam bentuk simpanan dan menyalurkan kepada masyarakat dalam rangka meningkatkan taraf hidup yang banyak. ${ }^{5}$

Dari beberapa pengertian bank di atas, maka yang dimaksud dengan bank konvensional adalah suatu jenis lembaga keuangan yang memberikan jasa, misalnya menghimpun dana dari masyarakat, menyalurkan dana kepada masyarakat dalam bentuk kredit, dan memperlancar transaksi perdagangan dengan menggunakan sistem

\footnotetext{
${ }^{1}$ Thomson, Dictionary Banking. London : The New Publishing co.. ltd. Ed. Ke II

${ }^{2}$ Muhammad Muslehuddin. Sistem Perbankan Dalam Islam, Terj. Aswin Simamora, (Jakarta: Rineka Cipta, 1994, Cet ke 2. h.1

${ }^{3}$ Thomas Suyatno, Kelembagaan Perbankan, akarta: Gramedia Pustaka Utama 1993, cet.5.h.1

${ }^{4}$ Undang-undang No. 14. th. 1967, Pokok-Pokok Perbankan

${ }^{5}$ Undang-undang No.7 th. 1992, Perbankan, Jakarta : Grramedia Pustaka Utama 1993,cet. 5, h.1
} 
perhitungan Bunga (Interest Forgone).

\section{Latar Belakang Terbentuknya Bank Konvensional}

Pada masa babilonia, yang diduga, sebagai usaha perbankan dan telah memegang peranan dan perdagangan adalah yunani dan romawi, bank pada masa itu masih bersifat tukar menukar mata uang dan berkembang menerima tabungan, menitipkan serta meminjamkan uang dengan memungut bunga pinjaman. ${ }^{6}$ Penukar uang dengan uang pada waktu dikenal dengan pedagang uang. Pada tahun 200 SM, di babilonia telah dikenal dengan istilah Bank yang menukarkan atau meminjamkan emas dan perak dengan tingkat bunga $20 \%$ setiap bulan dan disebut sebagai temples of babylon. ${ }^{7}$ Setelah masa Babylon th 500 SM. Di yunani didirikan semacam yang dikenal dengan Greek Temple. Menerima simpanan dengan memungut biaya penyimpanan serta menyimpan kembali kepada masyarakat pada saat itu pula banking-banking swasta muncul.

Lembaga perbankan pertama kali terbentuknya di yunani pada tahun 560 SM, setelah yunani, terbentuk pula usaha bank di Romawi yang operasinya telah lebih luas, seperti tukar menukar mata uang, menerima deposito, memberikan kredit sertta mentransfer modal.

Pada tahun 509 SM. Perbankan jatuh atau merosot bersamaan dengan jatuhnya kota Roma, namun pada tahuun 527-565 perbankan mulai bangkit lagi karena adanya yustinianuns mengkodifikasikan hukum romawi di konstantinovel. Perkembangan ini sejak adanya perdagangandenganCina.IndiadanEthiopia, sehinggayangditetapkan sebagai mata uang internasional adalah mata uang Kostantinopel. Perdagangan itu berkembang ke Asia barat (Timur tengah) dan Eropa sehingga dikenal sebagai pusat perdagangan seperti kota Alexandria, Venesia dan Pelabuhan-pelabuhan di utara selatan. Pada tahun 17 didirikanlah bank venezia yang dipakai untuk membiayai perang, dan tak lama kemudian pada tahun 1320 berdirilah bank of benoa dan bank barcelona. ${ }^{8}$ Dari kedua kota tersebut berpindahlah sistem bank keeropa. Pada tahun 1696 bank of england didirikan di Inggris. ${ }^{9}$

\footnotetext{
${ }^{6}$ Thomas Suyatno, Kelembagaan Perbankan, h. 3

${ }^{7}$ Thomas Suyatno, Kelembagaan Perbankan, h.3

${ }^{8}$ Thomas Suyatno, Kelembagaan Perbankan, h 3

${ }^{9}$ Fuad Moh. Fahruddin, Riba dalam Bank, Koperasi, Perseroan dan Asuransi, Bandung: Ma'Arif,
} 
Pada abad pertengahan inilah perbankan modern mulai mengalami perkembanagn dan kemudian mengalami perkembangan pada ke 1819. ${ }^{10}$

Didirikannya bank di Indonesia pada tanggal 10 Oktober 1827, yang dikenal dengan De Japaneshe Bank NV., kemudian di nasionalisir oleh pemerintah RI pada tanggal 6 Desember 1951 menjadi Bank Sentral di Indonesia berdasar UU No. 13. tahun 1968. ${ }^{11}$ Bank umum nasional adalah sebagai bank"

Konvensional yang merupakan salah satu bank nasional tertua yang telah mengalami perubahan zaman. Bank Umum Nasional (BUN) didirikan pada tanggal 2 september 1952 setelah Indonesia merdeka oleh para tokoh politik dari Partai Nasional Indonesia (PNI), dengan tujuan ingin membangun perekonomian nasional yang belum tertangani oleh bank-bank yang ada pada saat itu. ${ }^{12}$

Bank Umum Nasional mengalami peningkatan yang cepat sehingga membuka II jaringan cabang di berbagai kota, sejak tahun 1954 mendapat izin untuk beroperasi sebagai bank devisa luar negeri dan berhubungan korespondensi dengan bank internasional. Sebagai bank devisa, direksi aktif keluar negeri untuk membina hubungan dengan bank-bank korespondensi dalam rangka peningkatan bank tersebut. Misalnya pada saat sekarang ini, sistem pengelolaan bank misi bisnis tidak jarang di warnai oleh unsur-unsur politik.

\section{Sistem Operasional Bank Konvensional}

Sisitem operaional yang digunakan bank konvensional adalah menggunakan sistem perhitungan bunga kredit atau pinjaman (invest note), sedangkan yang dimaksud dengan bunga itu adalah sebagai balas jasa yang diberikan bank kepada nasabah karena membeli atau menjual produknya, atau dengan kata lain bahwa bunga itu sebagai harga yang harus dibayar kepada nasabah karena memiliki simpanan dan harga yang harus dibayar oleh nasabah kepada bank karena nasabah sebagai pihak peminjam atau debitan.

\footnotetext{
1993, Ceet.4. h. 3

${ }^{10}$ Mohammad Zuhri, Riba dalam Al-Qur'an dan Masalab Perbankan, Jakarta : Raja Grafinda Persada, 1996, Cet.1.h.143.

11 Thomas Suyatno, Kelembagaan Perbankan, h. 3

${ }^{12}$ Bank Umum Nasional, Sejarah Perkembangan BUN, Diklat BUN, h.6. tt.
} 
Mengenai tinggi rendahnya suku bunga di tengah masyarakat karena dipengaruhi oleh berbagai faktor, yakni: Likuiditas masyarakat, Ekspestasi, Inflasi, Besarnya suku bunga dalam Negeri dan Ekpektasi perubahan nilai tukar dan premi atas resiko. ${ }^{13}$

\section{Bank Syariah Sebuah Kajian Teori Antara Sistem dan Operasional}

Bank syariah merupakan bank yang secara operasionalnya berdasarkan konsep muamalah secara Islam yang sesuai dengan garisgaris yang telah ditentukan dalam Al-Qur'an dan As-Sunnah.

Adapun pengertian Bank Syariah adalah bank yang beroperasi sesuai dengan prinsip syariah Islam, dengan kata lain Bank yang sistem operasinya mengacu pada ketentuan-ketentuan yang telah ditentukan oleh Al-Qur'an dan hadits rasul'14. Ada juga yang mengartikan bahwa bank syariah itu adalah lembaga keuangan yang usaha pokoknya memberikan kredit dan jasa-jasa di dalam pembayaran serta pegedaran uang yang pengoperasiannya disesuaikan dengan prinsip syariat Islam. ${ }^{15}$

Dalam peraturan Pemerintah Republik Indonesia No. 72 tahun 1992 bahwa bank yang berdasarkan konsep bagi hasil berdasarkan syariat yang dipergunakan oleh suatu bank dalam hal pertama, menetapkan imbalan yang akan diberikan kepada masyarakat. Sehubungan dengan penggunaan dana masyarakat yang dipercayakan kepadanya. Kedua, menetapkan imbalan yang akan diberinya sehubungan dengan penyediaan dana kepada masyarakat dalam bentuk pembiayaan baik untuk keperluan investasi maupun modal kerja. ${ }^{16}$

\section{Latar Belakang Terbentuknya Bank Syariah}

Bentuk-bentuk perdagangan memang ada sebelum Islam yang kemudian dikembangkan pada zaman modern ini seperti, al-jarah atau kasing, al-ba'i'u Bisamanin ajil atau instalment-sal, musyarakah atau join venture.pinjam dengan tambah bunga atau riba. Serta kredit

\footnotetext{
${ }^{13}$ Bank Indonesia, Sistem Perbankan dan Peranan Perbankan, dan Dampaknya dalam Meningkatkan Kesejabteraan Ekonomi, makalah dalam lokakarya bunga bank dan perbankan, Bogor, tahun. 1990

${ }^{14}$ Kamaen Purwata Atmaja, Apa dan Bagaimana Bank Islam, Yogyakarta : Dana Bakti Wakaf, 1992, Cet. 1. h. 1

${ }^{15}$ Ensiklopedi Islam, Jakarta : Ichbar baru, Van Hoeve, 1994 h.45

${ }^{16}$ Faisal Afif, Strategi dan Operasional Bank. Bank : Ersico. 1996, h. 219
} 
pemilikan barang atau al murabahah. ${ }^{17}$ Bentuk-bentuk perdagangan ini berkembang di jazirah Arab karena letaknya sangat strategis. Seperti di Mekkah, Jeddah dan Madinah. Jazirah Arab yang berada di jalur perdagangan antara asia dan afrika-eropa kemungkinan besar dipengaruhi oleh bentuk-bentuk ekonomi Mesir purba, Yunani kuno dan Romawi, pada tahun 2500 SM. Mereka telah mengenal sistem perbankan. Babilonia wilayah Irak juga mengenal sistem perbankan pada tahun 2000 SM. Pada tahun 2633. Islam melarang praktek riba yang ditujukan keapda lembaga perbankan, larangan membungakan tidaklah hanya agama Islam yang melarang, namun agama samawi lainnya juga ikut melarang seperti kristen dan yahudi. ${ }^{18}$ Seperti dalam kitab exodus pasal 22 ayat 25. dinyatakan jika meminjamkan uang kepada salah seorang maka janganlah engkau berlaku sebagai penagih hutang terhadap dia, jangan engkau bebankan bunga uang kepadanya. Demikian pula dalam kitab Devtoronotif pasal 23 ayat 19 dinyatakan jangan engkau membungakan uang kepada saudaramu baik uang maupun bahan makanan atau apa saja yang dapat dibungakan. ${ }^{19}$

Rasulullah Saw. memberikan rambu-rambu tentang sistem perdagangan mana yang berlaku dan dapat dikembangkan pada masa mendatang, serta sistem usaha mana yang sesuai dengan Islam dan mana yang tidak sesuai dengan ajaran Islam, diantara larangan ini adalah usaha yang mengandung riba dimana ayat larangan riba itu turun menjelang rasulullah wafat pada usia 60 tahun. Beliau tidak sempat memperjelas secara rinci tentang riba, dengan demikian peranan ijtihad sangat dibutuhkan untuk menggali konsepsi dasar tentang sistem perbankan modern yang sesuai dengan syariah Islam. ${ }^{20}$

Berdirinya bank Islam di tingkat internasional, muncul dalam konferensi negara-negara Islam sedunia di Kuala lumpur Malaysia pada tanggal 21-27 April tahun 1969, yang diikuti oleh 19 Negara sedangkan keputusan yang ditetapkan dalam konferensi tersebut adalah :

Pertama: Tiap keuntungan haruslah tunduk kepada hukum hutang dan rugi. Jika tidak ia termasuk riba, dan riba itu sendiri adalah

${ }^{17}$ Warkom Sumitro. Asas-asas Perbankan dan Lembaga-lembaga Terkait, Jakarta : Raja Grafindo Persada, 1997 . h. 6

${ }^{18}$ Warkom Sumitro. Asas-asas Perbankan dan Lembaga-lembaga Terkait, h 6

${ }^{19}$ Warkom Sumitro. Asas-asas Perbankan dan Lembaga-lembaga Terkait. h. 7

${ }^{20}$ Warkom Sumitro. Asas-asas Perbankan dan Lembaga-lembaga Terkait, h. 8 
haram hukumnya baik sedikit maupun banyak.

Kedua diusulkan supaya dibentuk Bank Islam yang bersih dari sistem riba dalam waktu secepat mungkin.

Ketiga, Sementara menunggu berdirinya bank, Islam, bank-bank yang menerapkan bunga dibolehkan beroperasi jika dalam keadaan darurat. ${ }^{21}$

Munculnya konsep teoritis tentang bank Islam pada tahun 1940an, namun belum bisa direalisasikan, hal ini disebabkan karena kondisi pada waktu itu belum memungkinkan, juga belum adanya pemikiran bank Islam yang positif. ${ }^{22}$ Pada bulan Desember 1970 Menteri luar negeri DKI mengadakan konferensi dengan gagasan untuk diadakan IDB (Islamic Development Bank) di Korachi yang dijadikan sebagai pelopor Bank Islam. Pada tanggal 20 Oktober 1975 IDB didirikan sesuai dengan 22 negara Islam. ${ }^{23}$

Langkah pertama untuk mendirikan bank islam di indonesia, berawal dari lokarya "Bunga Bank dan Perbankan" yang diselenggarakan oleh MUI pada tanggal 18-19 di Bogor dan dipertegas lagi dalam munas IV MUI di hotel sahid Jakarta pada tanggal 22-25 Agustus 1990. tidak semuanya penandatanganan akta pendirian PT. Bank Muamalah Indonesia pada tanggal 1 November 1991 di hotel syahid di hadapan notaris Yudo paripurno $\mathrm{SH}$, dengan akte notaris No. 1 tanggal 1 November 1991 (Izin Menteri Kehakiman No. C 2. 2413. H I 01.01. tanggal 21 maret 1992 No. 34. ${ }^{24}$ Komitmen pemberian saham sudah mulai bangkit sebanyak Rp. 84 Milyar. Dua hari berselang, masyarakat jawa barat diundang Bapak Suharto di Istana Bogor dalam acara silaturahmi Bapak suharto dengan masyarakat Jawa Barat dalam rangka penjualan saham pendirian bank syariah. ${ }^{25}$

Modal awal bank syariah adalah Rp. 500 Milyar pada tahap awal dapat dipenuhi dengan total komitmen modal disetorkan sebesar Rp. 106.126382.000,-dengan modal ini mulai beroperasi pada tanggal $1 \mathrm{Mei}$ 1992 per SK menteri keuangan RI. NO. 1223/MK. 013/1991 tanggal 5 November 1991, diikuti oleh izin usaha keputusan menteri keuangan

\footnotetext{
${ }^{21}$ Ensiklopedi Islam, h. 223

${ }^{22}$ Warkom Sumitro. Asas-asas Perbankan dan Lembaga-lembaga Terkait, h.7

${ }^{23}$ Sofyan Safri Harahap, Akuntansi Islam, Jakarta: Bumi Aksara 1997, h. 108

${ }^{24}$ Sofyan Safri Harahap, Akuntansi Islam, h 108

${ }^{25}$ Meraup modal di Istana Bogor, Berita Buana, Jakarta: 3. November . 1991.h. 1
} 
RI No. 430/KMK: 013/1992 Tanggal 24 April 1992. ${ }^{26}$ Kemudian pemerintah mengemukakan peraturan tentang bank berdasarkan bagi hasil. RI No.72 tahun 1992. Dengan persyaratan bahwa bank yang dapat melakukan kegiatan berdasarkan konep bagi hasil adalah bank umum ataupun bank perkreditan rakyat. ${ }^{27}$ Peresmian bank syariah diadakan pada hari jumat 12 Dzulqa'dah 1412/ tanggal 15 Mei 1992 di Puri Agung Sahid Jaya Hotel. Dan diresmikan oleh bapak Presiden Suharto dan wakil Presiden Sudharmono SH. Serta penandatanganan prestasi berdirinya Bank Syariah di Indonesia. ${ }^{28}$

\section{Sistem Operasional Bank Syariah}

Berdasarkan konsep operasional Bank Syariah terdiri atas lima sistem yaitu : (1)Sistem simpanan murni (2)Sistem bagi hasil dalam penyaluran dana bank syariah. (3)Sistem jual beli dan marjin keuntungan. (4)Sistem sewa (al-ijarah) (5)Sistem fee (jasa). Pejelasannya dapat dilihat dibawah ini:

Sistem simpanan murni atau al-wadiah merupakan fasilitas yang diberikan oleh bank syariah untuk memberikan kesempatan kepada pihak yang berkelebihan dan untuk menyimpan dananya di bank. Fasilitas ini bukan tujuan untuk infestasi. ${ }^{29}$

Pengertian wadiah yaitu :

$$
\text { يتزكه محندا لمودع." مودة ورعا الشئ بمعنى تزكة. وسمى الشئ الذى يدعة الانسان عند غيره ليحفظه له بالوديعة. لانة }
$$

Simpanan bank syariah ada tiga macam yaitu : Tabungan Mudharabah, Deposito Mudharabah dan Giro Wadiah.

Adapun yang dimaksud dengan Mudharabah yaitu:

$$
\text { على هارحب في اللغال. مبارة عن ان يدف شحص مالا للآفر ليتجر فية على ان يكون الربح بنيها على ما شرطا وا لخشارة }
$$

Tabungan mudharabah ini merupakan tabungan pihak ke III selaku sahibul mall dan pihak bank selaku mudarib. Keuntungan ini dibagi sesuai dengan rasio laba yang telah disepakati bersama.

\footnotetext{
${ }^{26}$ Modal Awal BMI, Kompas, (Jakarta: 3 November. 1991), h.1

${ }^{27}$ Faisal Afif, Strategi dan Operasional Bank. h. 20

${ }^{28}$ Sofyan Safri Harahap, Akuntansi Islam, h. 108

${ }^{29}$ Warkom Sumitro. Asas-asas Perbankan dan Lembaga-lembaga Terkait, h. 81

${ }^{30}$ M. Hidayat. Memahami Sistem Operasional Bank Islam, Bank Muamalat. h.1
} 
Ketentuan-ketentuannya diatur oleh bank yang bersangkutan. ${ }^{31}$ Yakni tidak dapat dilakukan dengan menggunakan cek. Sedangkan jenisjenis tabungan mudharabah yaitu : tabungan mudharabah (TABAH), tabungan trendy, tabungan haji, tabungan qurban, dan tabungan umat. Dan fasilitas dengan diperoleh dalam tabungan antara lain ATM, Phone Banking, dan Asuransi Kecelakaan tanpa dibebani biaya premi.

Deposito mudharabah adalah simpanan pihak ke III di bank dalam mata uang rupiah atau asing yang penarikannya hanya dapat dilakukan pada saat jatuh tempo, sesuai dengan jangka waktunya. Demikian juga prinsip operasionalnya adalah nasabah bertindak sebagai pemilik modal (sohibul mal), dan bank bertindak sebagai pengusaha (mudharib).

Giro wadiah, adalah merupakan simpanan pihak ke III kepada Bank yang penarikannya dapat dikatakan sewaktu-waktu dengan menggunakan cek, bilyet giro atau pemindah bukuan. Sedang prinsip operasionalnya adalah nasabah sebagai penitip (dalam hal dana) dan bank sebagai pemegang amanah yang diperbolehkan menggunakan sekaligus mempertanggungjawabkan menggunakan sekaligus mempertanggung jawabkannya titipan dana tersebut. ${ }^{32}$

Sistem bagi hasil, Sistem ini merupakan tata cara pembagian hasil usaha antara penyedia dana dan pengelola dana, yang terjadi antara bank yang dengan penyimpan dana, ini dapat berbentuk mudharabah dan musyarakah arti mudharabah yaitu :

$$
\begin{aligned}
& \text { المشاركة معنا هالغة : حط احد لمالين با الأخر الجيث لا يمتزان عن بعضها، اصطلاحا، ليختلف باحتلاف انو عها } \\
& \text { لان الشركة تتوع الى شركة مفا وضة. }
\end{aligned}
$$

Musyarakah dalam bank syariah diartikan sebagai suatu perkongsian antara dua pihak atau lebih dalam suatu proyek, dimana masing-masing pihak berhak atas segala keuntungan dan bertanggung jawab akan segala kerugian yang terjadi sesuai dengan pernyataan masing-masing.

Bank syariah dalam kegiatan pembiayaan melakukan ketentuan-

${ }^{31}$ Moh. Assyaf, al-Abkamul Fighiyah fil Mazabibil Islamiyah al-Arba'ah, Beirut: Darihya al-ulum 1988, Cet. 3 jilid 2. h. 246.

${ }^{32}$ Moh. Assyaf, al-Abkamul Fiqhiyah fil Mazabibil Islamiyah al-Arba'ah, h. 2.

${ }^{33}$ Moh. Assyaf, al-Abkamul Fiqhiyah fil Mazabibil Islamiyah al-Arba'ah h 4. 
ketentuan sebagai berikut Pertama, Pembiayaan dana bank syariah dengan nasabahnya melakukan kerja sama dengan memberikan dana (sumber dana berasal dari kedua belah pihak yaitu shahibul mal dan mudharaib). Kedua, Dalam menggunakna dana pihak shahibul mal (bank) "boleh" ikut serta dalam meminjam mudharib. Ketiga, Shohibul mal (Bank) "boleh " saja meminta jaminan, Keempat, Kegiatan pembiayaan yang dilakukan oleh bank syariah berdasarkan musyarakah berupaL/C dan Join Financial. ${ }^{34}$

Mudharabah dari sisi penyaluan dapat diartikan suatu perkongsian antara kedua belah pihak, dimana pihak pertama (Shohibul Mal) menyediakan dana dan pihak kedua (mudharib) bertanggung jawab atas pengelolaan usaha. Keuntungan dibagikan sesuai dengan, perbandingan laba yang telah disepakati bersama. Advance. Manakala terjadi kerugian maka shahibul mal akan kehilangan sebagai imbalan dari kerja keras dan manajerial skill selama proyek berlangsung. ${ }^{35}$ Sistem Jual Beli dan Marjin Keuntungan pengertianya adalah

$$
\begin{aligned}
& \text { البيع تعريفها لغة : مقابلة شيئ، اصطلاحا مبادلة هال بمال على وجه محصوص اوهو مبادلة شيئ مر نحوب فيه بمشلة }
\end{aligned}
$$

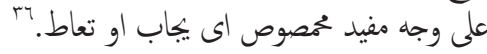

Sistem ini menerapkan suatu tata cara jual beli dimana pihak bank akan membeli terlebih dahulu barang yang dibutuhkan atau mengangkat nasabah sebagai agen dan nasabah dalam kapasitasnya sebagai bank melakukan pembelian-pembelian barang atas nama bank, kemudian bank menjual barang itu kepada nasabah dengan harga beli ditambah keuntungna. ${ }^{37}$

Sistem Sewa (al-Ijarah/al-Ta'jiri) yaitu

$$
\text { الإجارة مشتقة من الاجر وهو العوض، ومنه سمى التواب اجراوفى الشرع عقد على المنا فع بهوض }
$$

Sistem sewa dalam bank syariah ada dua : yakni al $i$ Jarah dan al-Ta'jiri. Al-ijarah yaitu merupakan perjanjian swwa yang memberi kesempatan keapda penyewa untuk memanfaatkan barang yang disewa dengan imbalan uagn sewa yang sesuai dengan persetujuan, setelah masa sewa berakhir barang akan di kembalikan kepada si

\footnotetext{
${ }^{34}$ Warku Sumitro, Asas-Asas Perbankan Islam dan Lembaga-lembaga Terkait, 8

${ }^{35}$ Warku Sumitro, Asas-Asas Perbankan Islam dan Lembaga-lembaga Terkait, h. 226.

${ }^{36}$.Wahbah. Az zuhaili, al-Fiqh al-Islami wa Adillah, Damaskus, den Al-fikr 986, cet. II jilid IV. h. $344-345$.

${ }^{37}$ Warku Sumitro, Asas-Asas Perbankan Islam dan Lembaga-lembaga Terkait, h. 1
} 
pemilik. Sedangkan al-Ta'jiri adalah suatu perjanjian kontrak sewa yang sama dengan al-jarah, tetapi setelah masa sewa berakhir pemilik barang yang disewa kepada penyewa dengan harga yang disepakati.

Sistem Fee (Jasa) Sistem ini adalah sistem kegiatan yang meliputi seluruh layanan non pembagian yang diberikan bank, bentuk jasa yang berdasarkan konsep ini yaitu : a. pemberian garansi denan konsep dasar al-kafalah, yaitu bank dapat membeirkan garansi atau permintaan nasabah untuk menjamin pelaksanaan proyek pemenuhan kewajiban tertentu oleh pihak yang dijamin, dan keving inkaso serta c. pemberian transfer.

\section{Persamaan Sistem Bank Konvensional dan Bank Syariah Pada konteks Meraih Keuntungan Dalam Sistem Bunga dan Bagi Hasil}

Persamaan antara sistem bunga dan sistem bagi hasil, dilihat dari perannya adalah keduanya merupakan sistem yang dipergunakan oleh lembaga-lembaga perbankan dalam penyaluran dana kepada masyarakat. Pihak kreditur (Bank) dan debitur (Nasabah) masingmasing mendapatkan keuntungan

Pihak debitur (Nasabah) memanfaatkan fasilitas yang telah diberikan oleh Bank dan membayarnya dengan cara berangsur. Sedangkan pihak kreditur juga mendapatkan keuntungan dengan sejumlah dana dari pihak debitur berdasarkan perhitungan sistem bunga dan sistem bagi hasil.

Dengan demikian jelaslah bahwa bunga dan bagi hasil adalah sarana utama dalam meraih keuntungan, ${ }^{38}$ baik lembaga perbankan maupun lembaga lainnya. Namun antara kedua sistem tersebut ada perbedaan persepsi terhadap kemungkinan keuntungan yang hendak di raih.

\section{Perbedaan Sistem Bank Konvensional dan Bank Syariah sebuah kajiana Sistem Bunga dan Bagi Hasil}

Perbedaan sangat mendasar antara sistem bunga dengan bagi hasil adalah pada sistem bunga dalam bank konvensional, penentuan

${ }^{38}$ Moh. Zuhri, Riba dalam Al-Qur'an dan Masalah Perbankan Jakarta : Raja Grafindo Persada 1996 , cet. I. h. 166 
bunga dibuat pada waktu akad tanpa berpedoman pada kesepakatan bersama (pihak bank yang menentukan) dan apakah perhitungan sistem bunga dapat menyulitkan nasabah untuk membayar angsuran atau tidak. Sedangkan pada sistem bagi hasil penentuan resiko keuntungan berdasarkan kesepakatan bersama antara pihak bank dengan nasabah dengan berpedoman pada kemungkinan tidak memberatkan pihak nasabah dalam mengangsur dana tidak merugikan pihak bank.

Pada sistem bunga, suku pinjaman bank konvensional dan suku bunga simpanan masing-masing akan saling mempengaruhi. Maka apabila suku bunga simpanan tinggi otomatis suku bunga pinjaman ikut tinggi. Sedangkan dalam sistem bagi hasil tidak demikian.

Pada sistem bunga, tinggi rendahnya bunga dipengaruhi oleh target laba (keuntungan) yang diinginkan oleh pihak bank, jadi apabila laba yang di inginkan besar maka bunga ikut besar pula dan sebaliknya, sedangkan pada sistem bagi hasil tidak adanya demikian.

\section{Penutup}

Persamaan kedua sistem (sistem bunga dan sistem bagi hasil) pada bank konvensional dan bank syariah para pihak yaitu kreditur (bank) dan debitur (nasabah) masing-masing mendapatkan "keungtungan" dalam segi bisnis tetapi akan berbeda jika dilihat dari sisi normatif atau regulasi yang terkait masing masing.

Sedangkan perbedaannya, dalam bank konvensional sistem bunga. Tinggi rendahnya suku bunga dipengaruhi oleh pihak bank bank, sedangkan dalam sistem bagi hasil rendahnya suku bunga disepakati oleh kreditur dan debitur.

\section{Pustaka Acuan}

Az zuhaili, Wahbah, al-figh al-Islami wa adillah, Damaskus, den Al-fikr 1986.

Afif, Faisal, Strategi dan Operasional Bank. Bank : Ersico. 1996.

Assyaf, Moh., al-ah kamul Fighiyah fil Mazahibil Islamiyah al-arba'ah,

Beirut: Darihya al-ulum. 1988.

Bank Umum Nasional, Sejarah Perkembangan BUN, Diklat BUN.

Bank Indonesia, Sistem Perbankan dan Peranan Perbankan, dan Dampaknya 
dalam Meningkatkan Kesejahteraan Ekonomi, makalah dalam lokakarya bunga bank dan perbankan, Bogor, 1990.

Ensiklopedi Islam, Jakarta : Ichbar baru, Van Hoeve, 1994.

Fahruddin, Fuad Moh., Riba dalam Bank, Koperasi, Perseroan dan Asuransi, Bandung: Ma' Arif, 1993.

Hidayat, M, Memahami Sistem Operasional Bank Islam, Bank Muamalat

Harahap, Sofyan Safri, Akuntansi Islam, Jakarta: Bumi Aksara. 1997.

Muslehuddin,Muhammad, Sistem Perbankan Dalam Islam, Terj. Aswin Simamora, Jakarta: Rineka Cipta, 1994.

Meraup modal di Istana Bogor, Berita Buana (Jakarta) 3. November . 1991.

Modal Awal BMI, Kompas, Jakarta: 3 November. 1991.

Undang-undang No. 14. th. 1967, Pokok-Pokok Perbankan.

Undang-undang No.7 th. 1992, Perbankan, Jakarta : Grramedia Pustaka Utama 1993.

Purwata Atmaja, Kamaen, Apa dan Bagaimana Bank Islam, Yogyakarta : Dana Bakti Wakaf, 1992.

Thomson, Dictionary Banking, London: The New Publishing co. ltd. Ed. Ke II.

Suyatno, Thomas, Kelembagaan Perbankan, Jakarta: Gramedia Pustaka Utama 1993.

Sumitro, Warkom Asas-asas Perbankan dan Lembaga-lembaga Terkait, Jakarta: Raja Grafindo Persada, 1997.

Zuhri, Mohammad Riba dalam Al-Qur'an dan Masalah Perbankan, Jakarta : Raja Grafinda Persada, 1996. 